\title{
Benign peripheral nerve sheath tumors of the extremities: a study of one hundred patients
}

\section{Ekstremitelerin iyi huylu periferik sinir kılıfı tümörleri: Yüz hastanın analizi}

\author{
Hüseyin Bilgehan Cevik ${ }^{1}$, Sibel Kayahan ${ }^{2}$, Engin Eceviz ${ }^{3}$, Seyit Ali Gümüştaş \\ ${ }^{1}$ Dışkapı Yıldırım Beyazıt Eğitim ve Araştırma Hastanesi, Ortopedi ve Travmatoloji Kliniği, Ankara, Türkiye \\ ${ }^{2}$ Kartal Dr. Lütfi Kırdar Eğitim ve Araştırma Hastanesi, Patoloji Kliniği, İstanbul, Türkiye \\ ${ }^{3}$ KaKartal Dr. Lütfi Kırdar Eğitim ve Araştırma Hastanesi, Ortopedi ve Travmatoloji Kliniği, İstanbul, Türkiye
}

Dergiye Ulaşma Tarihi: 19.11.2019 Dergiye Kabul Tarihi:12.12.2019 Doi: 10.5505/aot.2020.07641

\section{ÖZET}

GİRIŞ ve AMAÇ: Benign periferik sinir kılıfı tümörleri (BPSKT), sik görülen ve tedavisi zorlu tumorlerdir. BPSKT'lerin cerrahi tedavisinde ana hedef nörolojik fonksiyonların korunarak tümörün eksizyonudur. $\mathrm{Bu}$ çalışmanın amacı BPSKT hastalarinin demografik özelliklerini, klinik prezentasyonlarını, tumorun cerrahi ve patolojik bulgularını ve morbidite açısından sonuçlarını araştırmaktır.

YÖNTEM ve GEREÇLER: 2006 ve 2016 yılları arasında üçüncü basamak hastanemizde cerrahi olarak tedavi edilen ekstremite yerleşimli BPSKT'li 100 hastanın klinik ve radyolojik bulgularının retrospektif bir analizi yapild1.

BULGULAR: Bu seride 55 schwannom, 38 nörofibrom, 5 pleksiform nörofibrom ve 2 pleksiform schwannom olmak uzere 52'si erkek 48'i kadın toplam 100 hastanın değerlendirilmesi yapıldı. En sik klinik prezentasyon ağrılı kitleydi. Malignite şüphesi olan 20 hastaya ameliyat öncesi biyopsi yapıldı. Bu 20 hastanın poatoperatif takiplerinde 6'sında motor defisit, 7 'sinde sürekli ağr1 saptandi. \%5 (5/100) hastada nüks görüldü. BPSKT 'lerin $\% 23$ 'ü (23/100) NF tip-1 ile ilişkiliydi. Ortalama takip süresi 77 aydı.

TARTIŞMA ve SONUÇ: BPSKT'ler tümörün tamamen eksizyonu ile mükemmel klinik sonuçlara sahiptir. BPSKT'leri her yaşta görülebilirler ve genellikle ele gelen kitle şikayetiyle başvururlar. Çoğu BPSKT'lerini schwannomalar oluşturmaktadır. Ortopedistler bir biyopsi ve / veya cerrahi işlemden kaynaklanan olası sinir hasarını göz önünde bulundurmalıdır. Malignite şüphesi ile olası sinir hasarı arasındaki denge göz önüne alındığında, biyopsi dikkatle planlanmalıdır.

Anahtar Kelimeler: Benign periferik sinir kılıfı tümörü, Nörofibrom, Schwannom, Pleksiform

\begin{abstract}
INTRODUCTION: Benign peripheral nerve sheath tumors (BPNST) are common tumors, with challenging management. The main target of surgical management of BPNSTs is excision of the tumor with preservation of neurological functions. The aim of the present study was to investigate the demographic features, clinical presentations, surgical and pathological findings, and outcomes of BPNSTs in respect of morbidity.

METHODS: A retrospective analysis of clinical and radiological findings of 100 patients with BPNSTs involving the extremities who were surgically treated at our tertiary hospital center, between 2006 and 2016.

RESULTS: In this series, evaluation was made of 100 patients comprising 52 males and 48 females with 55 schwannomas, 38 neurofibromas, 5 plexiform neurofibromas, and 2 plexiform schwannomas. The most presenting feature was painful mass. A pre-operative biopsy was performed in 20 patients with suspicion of malignancy. Of these 20 patients, 6 had post-operative motor deficits and 7 had continuous pain in the follow-up period. Recurrence was seen in 5\% (5/100) patients. There were 23\% patients $(23 / 100)$ with BPNSTs were associated with NF type-1. The overall average follow-up was 77 months.

DISCUSSION AND CONCLUSION: BPNSTs have great clinical outcome with total excision of the tumor. BPNSTs are tumors that can be seen at any age, and generally they are presented with a palpable mass. Most of the BPNSTs are schwannomas. Orthopedic surgeons should in mind the possible nerve damage caused by a biopsy and/or surgery. Considering the balance between malignancy suspicion and possible nerve damage, biopsy should be planned carefully.

Keywords: Benign peripheral nerve sheath tumor, Neurofibroma, Schwannoma, Plexiform
\end{abstract}




\section{INTRODUCTION}

Benign peripheral nerve sheath tumors (BPNSTs) include schwannomas and neurofibromas that are a subset of neuroepithelial tumors. Histologically, schwannoma is an encapsulated tumor, growing within the nerve sheath, while neurofibroma is less circumscribed, not encapsulated and grows within the endoneural tissue(1). Plexiform schwannoma is an uncommon variant of Schwann cell tumor, characterized either grossly or histologically by a plexiform pattern of intraneural growth often with multi-nodularity(2, 3).Plexiform neurofibroma is also an uncommon variant of neurofibroma, a benign tumor of peripheral nerves arising from a proliferation of all neural elements, and present with intra- and extrafascicular growth along tissue planes and involve the entire nerve without capsule formation (4-6).

BPNSTs constitute10-12\% of benign soft tissue tumors (7-9) and are biologically less aggressive tumors with an excellent prognosis compared to malignant peripheral nerve sheath tumors(10-12). Generally both BPNSTs and malignant peripheral nerve sheath tumors occur sporadically $(13,14)$. However, in some cases, there is association with neurofibromatosis (NF) type-1, which is an autosomal dominant neurocutaneous disorder with an estimated incidence of 1 in 2500 births $(4,8,15)$.One of the most characteristic feature of NF-1 is multiple neurofibromas, although NF-1 was previously referred to as peripheral neurofibromatosis (16). In literature, the coexistence of malignant PNSTs and NF-1 has been reported to be around $10 \%(17,18)$.

There are many case reports, small case series, and only a few large case series in literature $(4,8,19,20)$, in which the authors have tried to describe surgical and clinical experience of dealing with this problem involving several peripheral nerves. The main target of surgical management of BPNSTs is excision of the tumor with preservation of neurological functions. The aim of the present study was to investigate the demographic features, clinical presentations, surgical and pathological findings, and outcomes of BPNSTs in respect of morbidity. However, our hypothesis is that BPNSTs are completely excisable tumors with preservation of neurological functions and an acceptable risk of neurological morbidity.

\section{MATERIALS and METHODS}

A retrospective analysis was made of 100 patients with BPNSTs involving the extremities, who were surgically treated at our tertiary hospital center, between 2006 and 2016. The study was approved by the local institutional review board, and all the patients gave their written, informed consent. The clinical records, radiological images, and follow-up data were obtained from patient charts, the picture archiving and communication system, and pathology reports at the hospital.The clinical information about the interval between first sign and diagnosis, the presenting symptom and pre/post-operative neurological examination were obtained from clinical records. The pathological and surgical information about the tumor location, tumor dimension, and extent of excision was also collected and evaluated. From a review of the files, 134 patients were identified with pathological diagnosis of BPNST. Of these 134, 4 patients were excluded as the tumor was around the spine, and 3 patients died during this period. The remaining 127 patientswere invited for final evaluation, but 27 patients did not attend.Therefore, a final total of 100 patients were evaluated in the study, and these comprised 55 schwannomas, 38 neurofibromas, 5 plexiform neurofibromas, and 2 plexiform schwannomas. 
All patients had undergone preoperative magnetic resonance imaging (MRI) to determine the size, limits and anatomic location of the tumors.In almost all cases, MRI showed a well-defined nerve-related tumor with contrast enhancement. It was also decided from the MRI results which patients would undergo a biopsy procedure before excision surgery.The heterogenicity, peripheral enhancement pattern, and perilesional edemalike zone on $\mathrm{T} 1$ and $\mathrm{T} 2$ weighted images were evaluated for suspicion of malignancy. However, patients were evaluated for clinical suspicion of malignancy include weight loss, nocturnal pain and rapidly growing mass. If there were any of these MRI and/or clinical findings, it was led us to perform biopsy. Ultrasound guided biopsy was performed for deeply located lesions.

The surgeries for excision of BPNSTs were performed according to microsurgery principles. A longitudinal incision was made in the epineurium until the surface of the tumor was exposed. Fascicles adherent to the capsule were bluntly dissected off carefully after retracting nerve fascicles that surrounded the tumor. The tumor was then removed en bloc with the capsule (Figure 1). Some BPNSTs had 1 or more fascicles entering and/or leaving the tumor and some of them needed nerve graft repair, and required careful dissection.

Clinical follow-up data were obtained from patient charts covering the first postoperative day, then $1,3,6$ and 12 months, and every subsequent year after surgery, and the final clinical evaluation. All patients were invited to attend a final clinical evaluation and if the patient had any symptom indicating recurrence, the patient was applied with MRI or electromyographic evaluation.

\section{RESULTS}

Evaluation was made of 100 patients comprising 52 males and 48 females with 55 schwannomas, 38 neurofibromas, 5 plexiform neurofibromas, and 2 plexiform schwannomas. The overall average follow-up was 77 months. There were $23 \%$ patients (23/100) with BPNSTs were associated with NF type-1.Of 20 patients undergoing biopsy, 6 had postoperative motor deficits and 7 had continuous pain in the follow-up period.All patients underwent MRI before the excision procedure. The clinical features and distribution of all the tumors are summarized in Table 1.

\section{Schwannomas}

There were 55 patients, comprising 34 males and 21 females (M:F ratio, 1.61: 1) with amean age of 45 years (range, $8-82$ years) at presentation and an average follow-up of 78 months (range, 24 - 148 months). The interval between first signs and diagnosis was long at mean 4.7 years (range, 3 months - 9 years). The presenting symptom in 52 patients $(94.5 \%)$ was a palpable mass, and in 40 patients $(72.7 \%)$ pain syndromes; 9 patients had radicular pain and 31 had radicular and localized pain. In the preoperative examination, superficial sensory function impairment was detected in 42 of 55 patients $(76.3 \%)$ and motor deficit in 11 of 55 patients (20\%).Complete excision of the tumor was performed extra-capsularly and a nerve graft repair was performed in 4 patients. Patients who underwent nerve grafting had motor deficits prior to surgery. The nerves of these patients with motor deficits were squeezed between the tumor and tissues such as fascia or bone. The greatest mean tumor size was $2.6 \mathrm{~cm}$ (range, 0.3 to $12 \mathrm{~cm}$ ). During the follow-up period,preoperative sensory deficitswere resolved in 36 of 40 patients (90\%). Improvement in motor function was observed in 3 of 11 patients (27.2\%). No recurrence was observed in any patient.

\section{Neurofibromas}

There were 38 patients, comprising 21 females and 17 males ( $\mathrm{F}: \mathrm{M}$ ratio, $1.23: 1)$ with amean age of 44 years (range, 15-86 years) at 
presentation and an average follow up of 78 months (range, 33 - 148 months). The interval between first signs and diagnosis was mean 2 years (range, 3 months - 10 years). In all patients the presenting symptom was pain. Of the 38 patients, 20 (53\%) had NF-1, and these were 9 males and 11 females with an average age of 36 years. Of the 38 patients, 17 (44.7\%) presented with a palpable mass. Superficial sensory function impairment, especially on percussion over the mass, was reported by 7 (18.4\%) patients and 3 patients $(7.9 \%)$ reported motor deficit before surgical excision. Complete excision of all the tumors was performed and a nerve graft repair was applied to 3 patients whom had motor deficit before the surgery. The greatest mean dimension of tumor size was $2.6 \mathrm{~cm}$ (range, $0.5-13 \mathrm{~cm}$ ).In 14 of the 38 patients the neurofibroma was associated with NF-1, and the recurrence rate was determined as $8 \%$ (3 of 38 patients). During the follow-up period, the motor strength improved in $10.5 \%$ of patients, worsened in $21.1 \%$, and remained unchanged in $68.4 \%$. No patient with preoperative neuropathic pain reported worsening of the pain postoperatively.

\section{Plexiform Neurofibromas}

All 5 patients were females with a mean age of 26 years (range, $4-56$ years). Three patients suffered from NF-1, which accounted for $14.3 \%$ of the total number of patients with NF1 (21 patients). The interval between first signs and diagnosis was mean 5 years (range, 6 months - 10 years). In 3 patients the presenting symptom was pain, while the other 2 patients presented with a palpable mass, which was on the hand. Subtotal excision was performed in 3 of 5 patients with plexiform neurofibroma. One was completely excised and there was no recurrence in 106 months of follow-up, one had recurrence in the 36th month after the excision and re-excision was performed, and in the third patient, the pain continued after the excision. Total excision was performed in 2 of
5 patients. One patient was followed up for 32 months without recurrence but with persistent paresthesia, and the other was followed up for 103 months without any complication or recurrence. The largest tumor size ranged from 1.4 to $6 \mathrm{~cm}$. During the follow-up period, the motor strength of the patients improved in $20 \%$ (1/5), and remained unchangedin $80 \%$ (4/5). Pain syndromes were completely or partially resolved in $40 \%$ (2/5) of cases.

\section{Plexiform Schwannomas}

The 2 patients were 1 female and 1 male, aged 52 and 42 years old, respectively. The female patient had 6 months duration of symptoms and the male 2 years. The presenting symptom in both patients was a palpable mass and pain. There was no recurrence in the female patient with 79 months follow up or in the male patient with 60 months. The greatest dimension of the tumor was $2.2 \mathrm{~cm}$ in the female patient and $2 \mathrm{~cm}$ in the male patient.

\section{DISCUSSION}

BPNSTs are manageable tumors with an acceptable risk of morbidity. However, surgery still remains the only viable treatment for BPNST patients.In this study, evaluation was made of four histological types of BPNSTs that were affecting the peripheral nervous system: schwannoma, neurofibroma, plexiform neurofibroma, and plexiform schwannoma.

It has been reported in literature that BPNSTs usually occur in early or middle adulthood and there is no obvious gender predilection $(4,5,21)$. In this study, the mean age at the time of the initial procedure was 43.5 years (range, 4 - 86 years), and there were 52 males and 48 females.

Superficial BPNSTs almost always present with a mobile mass located over the trace of a nerve, andless frequently, with pain and paraesthesia. Generally, neurofibromas present with pain, but the incidence of pain in schwannomas ranges from $0 \%$ to $100 \%(4,22)$. 
In a previous study of plexiform neurofibromas, the most common indication for excision was reported to be elective/cosmetic (23). In the current study, the incidence of pain was $95 \%(36 / 38)$ in neurofibromas and $64 \%(35 / 55)$ in schwannomas. In addition, $100 \%$ (2/2) of plexiform schwannomas, $60 \% \quad(3 / 5)$ of plexiform neurofibromas, and $95 \%$ of all BPNSTs (95/100) presented with a palpable mass.

The electromyogram may provide evidence of denervation activity with localized slowing or a block of conduction that indicates a nerve lesion. However, if some fibers are unaffected, the electromyogram may be normal $(4,5)$, as occurred in $15 \%(15 / 100)$ of our cases.

Gadolinium contrast MRI was applied to all patients preoperatively and that provided information about the tumor location, size, characteristics, fascicular orientation, and surrounding neurovascular relationship. Wasa et al said that the heterogenicity, peripheral enhancement pattern, and perilesional edemalike zone on $\mathrm{T} 1$ and $\mathrm{T} 2$ weighted images are useful for distinguishing malignant peripheral nerve sheath tumors from neurofibromas(24). We used those criteria to decide whether to perform a biopsy. T1 and T2-weighted images usually show homogeneously iso-intense and hyperintense images, respectively. The center of the lesion exhibits strong contrast enhancement or non-homogeneity. Suh et al stated that non-homogeneity is found only in NF (25). Artico et al reported no differences among patients related to the frequency of each type of enhancement (4). In the current study, there were no differences related to the frequency of each type of enhancement among the 100 patients ( 23 with $\mathrm{NF}$ ).

Levi et al recommended that MRI is applied and tertiary referral without biopsy when a PNST is suspected (26). The role of fine needle aspiration or core needle biopsy in the diagnosis of peripheral nerve sheath tumor is very limited (8). Patients with BPNSTs who have undergone a needle or open biopsy procedure prior to definitive excision have been reported to be at 2.7-fold higher risk of postoperative neurological deficits than those who underwent excision first (26). The biopsy procedure increases the risk of damaging fascicles and hemorrhage within the tumor, thus it may cause possible morbidity. Although a preoperative biopsy can confirm the accuracy of preoperative diagnosis, the risks associated with preoperative biopsy outweigh the benefits.However, if there is suspicion of malignant peripheral nerve sheath tumor, a preoperative biopsy is strongly indicated for treatment planning $(4,8)$. In the present study, preoperative biopsy was performed in 20 patients with suspicion of malignancy, which resulted in $30 \%$ postoperative motor deficits and $35 \%$ continuous pain in the follow-up period. In addition, this study covers only BPNSTs. Therefore, our results do not support to perform biopsy or not. Nevertheless, we believe that the presence of heterogeneity, peripheral enhancement pattern, and perilesional edema-like zone in MRI should lead us in favor of biopsy.

The excision of BPNSTs can be performed as subtotal excision (50\% or more) or gross total excision (>90\% of the tumor) that may or may not leave behind the tumor capsule attached to the fascicles (8). The decision for which type of excision is to be applied depends on the macroscopic nature of the tumor intraoperatively. The treatment of BPNSTs is challenging because the natural course of untreated tumors is mostly unknown and most patients present without motor deficits (4-6). The decision for surgery was based on the expected improvement of pain and the presence of paraesthesia. As in the current study, enucleation of the tumor should be performed with microsurgery principles. Neurofibromas have a tendency to grow intraneurally and because of that the surgical 
approach is challenging. Some have few fascicles that penetrate the tumor. The complete removal of the tumor may require sacrifice of the fascicle or in some cases all of the nerve, thereby causing functional disability. Nevertheless, neurofibromas may involve a single nerve fascicle, as was observed in $10 \%$ of the current study patients (4/38).Excision of the tumor with the fascicle did not result in injury to the nerve in any of these patients.

Artico et al reported that if there is severe neurological deficit, wide excision may be justified, and if mild or absent, intracapsular excision and grafting may give good results(4).In the current study, nerve grafting was performed in 3 patients (3/100) with neurofibromas, where it was not possible to salvage the nerve because of nerve damage.

In literature, recurrence rates have been stated to be lowest in schwannomas, low in neurofibromas, and high in plexiform variants of BPNSTs. $(4,8,19,27,28)$. Subtotal excision is known to be associated with an increased recurrence rate for all BPNSTs (20). In the current study, a 5\% (5/100) recurrence rate was detected in all BPNSTs. All 5 patients had subtotal excision of the tumor, and 5 of the other 95 patients also had subtotal excision but the tumors did not recur during mean 77 months follow-up.

Limitations of the present study included its retrospective nature, the absence of a malignant peripheral nerve sheath tumors, and the lack of clinical scores to support the our statements.

Neurofibromas and schwannomas are completely excisable tumors with an acceptable risk of injury to the nerve. Considering the balance between malignancy suspicion and possible nerve damage, biopsy should be planned carefully. However, plexiform tumors are generally subtotally excisable with risk of regrowth. As the tumorsin NF patientsare at risk of malignant transformation,the follow-up examinations of these patients should be more detailed.

\section{Conflict of interest: None.}
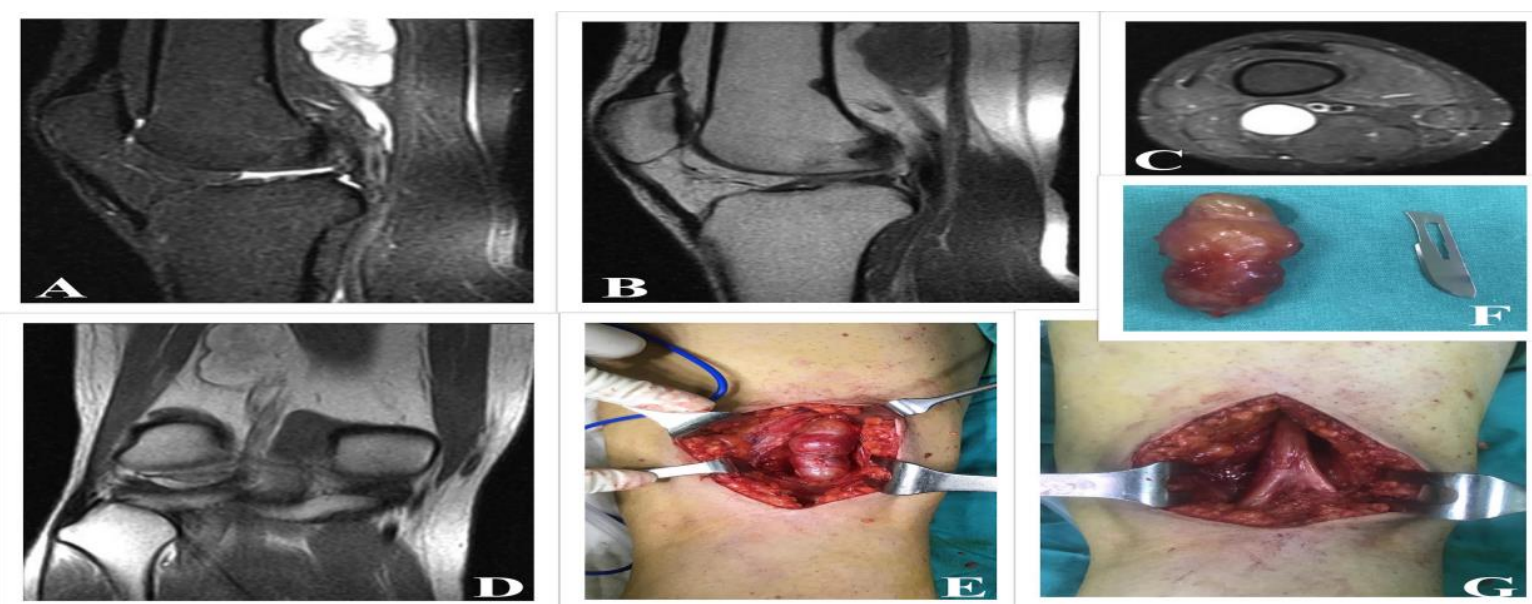

Figure 1: Neurofibroma at sciatic nerve bifurcation. A 23 years old male presented with painful swelling in the right posterior distal thigh region for last 6 months. He had no neurological deficit. MRI scan was revealed the following: A, Sagittal T2-weighted gadolinium-enhanced image. B, Sagittal T1-weighted image. C, Axial T2-weighted gadoliniumenhanced image. D, Coronal T1-weighted image. Posterior midline longitudinal incision was used to excision of tumor: E, Neurofibroma at sciatic nerve bifurcation. F, The excised neurofibroma. G, Intraoperative image showing the sciatic nerve after complete excision of the neurofibroma with anatomical continuity of the common peroneal and tibial nerves. 
Table 1: Summarizes the location, pre- and post-op clinical findings, surgical procedures and histopathological findings in 100 patients with BPNSTs of upper and lower limbs (NF: Neurofibromas, SCH: Schwannomas, PNF: Plexiform Neurofibromas, P-SCH: Plexiform Schwannomas)

\begin{tabular}{|c|c|c|c|c|c|c|c|c|c|c|c|}
\hline \multirow{2}{*}{$\begin{array}{l}\text { Location of BPNSTs } \\
\begin{array}{l}\text { BPNSTs of extremities } \\
(n=100)\end{array}\end{array}$} & \multicolumn{3}{|c|}{ Pre-op clinical findings } & \multicolumn{2}{|c|}{$\begin{array}{l}\text { Post-op clinical } \\
\text { findings }\end{array}$} & \multicolumn{2}{|c|}{ Surgery } & \multicolumn{4}{|c|}{ Histopathology } \\
\hline & Pain & Paresthesia & $\begin{array}{l}\text { Motor } \\
\text { deficit }\end{array}$ & $\begin{array}{l}\text { Motor } \\
\text { deficit }\end{array}$ & Pain & Total & Subtotal & NF & $\mathrm{SCH}$ & P-NF & $\begin{array}{c}\mathrm{P}- \\
\mathrm{SCH}\end{array}$ \\
\hline \multicolumn{12}{|l|}{ BPNSTs in upper limb $(n=68)$} \\
\hline Axillary Nerve $(n=6)$ & 5 & 4 & - & 1 & 2 & 5 & 1 & 2 & 4 & - & - \\
\hline Median nerve $(\mathrm{n}=9)$ & 9 & 3 & 1 & - & 1 & 9 & - & 2 & 5 & 2 & - \\
\hline $\begin{array}{l}\text { Anterior interosseous nerve } \\
(\mathrm{n}=2)\end{array}$ & 2 & - & 1 & 1 & - & 2 & - & 1 & - & - & 1 \\
\hline Radial nerve $(\mathrm{n}=3)$ & 3 & - & - & - & - & 3 & - & 1 & 2 & - & - \\
\hline $\begin{array}{l}\text { Posterior interosseous nerve } \\
(\mathrm{n}=5)\end{array}$ & 4 & - & 1 & 1 & 1 & 5 & - & 2 & 3 & - & - \\
\hline Ulnar nerve $(\mathrm{n}=9)$ & 9 & 1 & 1 & 1 & 2 & 7 & 2 & 4 & 4 & 1 & - \\
\hline $\begin{array}{l}\text { Cutaneous sensory nerves } \\
(\mathrm{n}=8)\end{array}$ & 8 & 3 & - & - & - & 8 & - & 2 & 5 & 1 & - \\
\hline $\begin{array}{l}\text { Musculocutaneous nerve } \\
(\mathrm{n}=7)\end{array}$ & 7 & - & - & - & - & 7 & - & 4 & 3 & - & - \\
\hline Digital nerves ( $\mathrm{n}=19)$ & 19 & 3 & - & - & 1 & 19 & - & 7 & 10 & 1 & 1 \\
\hline \multicolumn{12}{|l|}{ BPNSTs in lower limb $(n=32)$} \\
\hline Sciatic nerve $(\mathrm{n}=5)$ & 5 & 2 & 1 & 1 & 1 & 5 & - & 4 & 1 & - & - \\
\hline Femoral nerve $(\mathrm{n}=2)$ & 2 & - & 1 & 1 & - & 2 & - & 1 & 1 & - & - \\
\hline Peroneal nerve $(\mathrm{n}=2)$ & 2 & - & - & - & - & 1 & 1 & 1 & 1 & - & - \\
\hline Tibial nerve $(\mathrm{n}=3)$ & 3 & - & - & - & - & 3 & - & 2 & 1 & - & - \\
\hline Lateral plantar nerve $(n=3)$ & 3 & 1 & - & - & - & 3 & - & 1 & 2 & - & - \\
\hline Medial plantar nerve $(n=4)$ & 4 & 1 & - & - & 1 & 4 & - & - & 4 & - & - \\
\hline $\begin{array}{l}\text { Cutaneous sensory nerves } \\
(n=6)\end{array}$ & 6 & 3 & - & - & - & 6 & - & 2 & 4 & - & - \\
\hline Digital nerves $(\mathrm{n}=7)$ & 7 & - & - & - & - & 7 & - & 2 & 5 & - & - \\
\hline
\end{tabular}

\section{REFERENCES}

1. KARABULUT H, ACAR B, BABADENIZ MA, ŞIMŞEK G, GÜNBEY E, KARAŞEN RM. Brakiyal pleksustan kaynaklanan schwannom olgusu. Acta Oncologica Turcica. 2009;42(2):80-2.

2. Fletcher C, Davies S. Benign plexiform (multinodular) schwannoma: a rare tumour unassociated with neurofibromatosis. Histopathology. 1986;10(9):971-80.

3. Val-Bernal JF, Figols J, Vázquez-Barquero A. Cutaneous plexiform schwannoma associated with neurofibromatosis type 2 . Cancer. 1995;76(7):1181-6.

4. Artico M, Cervoni L, Wierzbicki V, D'andrea V, Nucci F. Benign neural sheath tumours of major nerves: characteristics in 119 surgical cases. Acta neurochirurgica. 1997;139(12):1108-16.

5. Donner TR, Voorhies RM, Kline DG. Neural sheath tumors of major nerves. Journal of neurosurgery. 1994;81(3):362-73.

6. Kline DG, Hudson AR. Nerve injuries: operative results for major nerve injuries, entrapments, and tumors: Saunders; 1995.

7. Gosk J, Gutkowska O, Mazurek P, Koszewicz M, Ziółkowski P. Peripheral nerve tumours: 30-year experience in the surgical treatment. Neurosurgical review. 2015;38(3):511-21.
8. Desai KI. The surgical management of symptomatic benign peripheral nerve sheath tumors of the neck and extremities: an experience of 442 cases. Neurosurgery. 2017;81(4):568-80.

9. Ozturk R, Arikan SM, Bulut EK, Kekec AF, Celebi F, Gungor BS. Distribution and evaluation of bone and soft tissue tumors operated in a tertiary care center. Acta orthopaedica et traumatologica turcica. 2019;53(3):189-94.

10. Montano N, D'Alessandris QG, D'Ercole M, Lauretti L, Pallini R, Di Bonaventura R, et al. Tumors of the peripheral nervous system: analysis of prognostic factors in a series with long-term follow-up and review of the literature. Journal of neurosurgery. 2016;125(2):363-71.

11. Ganju A, Roosen N, Kline DG, Tiel RL. Outcomes in a consecutive series of 111 surgically treated plexal tumors: a review of the experience at the Louisiana State University Health Sciences Center. Journal of neurosurgery. 2001;95(1):51-60.

12. Bağır EK, Açıkalın $A$, Gönlüşen $G$, Zorludemir $S$, Deveci MA. Hybrid peripheral nerve sheath tumors. Cukurova Medical Journal. 2019;44(3):1-.

13. Halliday AL, Sobel RA, Martuza RL. Benign spinal nerve sheath tumors: their occurrence sporadically and in neurofibromatosis types 1 and 2. Journal of neurosurgery. 1991;74(2):248-53. 
14. Varış O, Togral G, Arıkan M, Aydın M. Vaka Sunumu: Malign Periferal Sinir Kılıf Tümörü. ACTA ONCOLOGICA TURCICA.49(2):131-4.

15. Ferner RE, Gutmann DH. International consensus statement on malignant peripheral nerve sheath tumors in neurofibromatosis 1. AACR; 2002.

16. Lynch TM, Gutmann DH. Neurofibromatosis 1. Neurologic clinics. 2002;20(3):841-65.

17. Goertz O, Langer S, Uthoff D, Ring A, Stricker I, Tannapfel A, et al. Diagnosis, treatment and survival of 65 patients with malignant peripheral nerve sheath tumors. Anticancer research. 2014;34(2):777-83.

18. Gachiani J, Kim D, Nelson A, Kline D. Surgical management of malignant peripheral nerve sheath tumors. Neurosurgical focus. 2007;22(6):1-8.

19. Angelini A, Bevoni R, Biz C, Cerchiaro MC, Girolami M, Ruggieri P. Schwannoma of the foot: report of four cases and literature review. Acta Bio Medica Atenei Parmensis. 2019;90(1-S):214-20.

20. Guha D, Davidson B, Nadi M, Alotaibi NM, Fehlings MG, Gentili F, et al. Management of peripheral nerve sheath tumors: 17 years of experience at Toronto Western Hospital. Journal of neurosurgery. 2018;128(4):1226-34

21. Sala DC, Leombruni E, Del CR, Amillo SG. Tumors of nerve sheaths of the peripheral nerves. Annali italiani di chirurgia. 1992;63(4):445-50; discussion 50-1.

22. Karaman I, Oner M, Kafadar IH, Guney A, Argun M. Surgical excision of peripheral nerve schwannomas: analysis of 11 patients. Acta orthopaedica et traumatologica turcica. 2015;49(2):139-43.

23. Needle MN, Cnaan A, Dattilo J, Chatten J, Phillips PC, Shochat S, et al. Prognostic signs in the surgical management of plexiform neurofibroma: the Children's Hospital of Philadelphia experience, 1974-1994. The Journal of pediatrics. 1997;131(5):678-82.

24. Wasa J, Nishida Y, Tsukushi S, Shido Y, Sugiura $H$, Nakashima $H$, et al. MRI features in the differentiation of malignant peripheral nerve sheath tumors and neurofibromas. AJR Am J Roentgenol. 2010;194(6):1568-74

25. Suh J-S, Abenoza P, Galloway HR, Everson L, Griffiths H. Peripheral (extracranial) nerve tumors: correlation of MR imaging and histologic findings. Radiology. 1992;183(2):341-6.

26. Levi AD, Ross AL, Cuartas E, Qadir R, Temple HT. The surgical management of symptomatic peripheral nerve sheath tumors. Neurosurgery. 2010;66(4):833-40.

27. Kim DH, Cho Y-J, Ryu S, Tiel RL, Kline DG. Surgical management and results of 135 tibial nerve lesions at the Louisiana State University Health Sciences Center. Neurosurgery. 2003;53(5):111425.

28. Carvajal JA, Cuartas E, Qadir R, Levi AD, Temple HT. Peripheral nerve sheath tumors of the foot and ankle. Foot \& ankle international. 2011;32(2):1637. 